\title{
GENERAL MOTORS OF CANADA LTD. v. NAKEN: TWO CENTURIES FORGOTTEN
}

\author{
DENNIS PAWLOWSKI*
}

The case of General Motors of Canada Ltd. v. Naken ${ }^{1}$, may well be the leading example of a barrister's nightmare come true. Most assuredly, it is an example of the evils of protracted litigation and uncertainty in the law of representative actions in Canada.

The Naken case began in 1971 when General Motors of Canada undertook to market the "Firenza", a compact car manufactured in Great Britain by Vauxhall Motors Ltd. The vehicle, as unfortunate consumers were soon to discover, was so fraught with mechanical problems that it became the subject of much adverse publicity. This, together with pressure from consumer groups such as the "Disgruntled Firenza Owners' Association"', resulted in a discontinuance of sales and an offer by General Motors to credit each Firenza owner with $\$ 250.00$ toward the purchase of a new G.M. vehicle. Most Firenza owners found this solution unsatisfactory and rejected the offer.

On July 13, 1973, Naken and three others, claiming on behalf of themselves and on behalf of all Ontario purchasers of new 1971 and 1972 Firenzas, issued a writ and commenced an action against General Motors of Canada. After a preliminary demand for further and better particulars respecting the nature of the class and the alleged breaches, the defendant brought an application under Rule $126^{3}$ to strike out the plaintiff's claim. The issue to be determined was that of the proper construction of the class within the meaning of Ontario Rule $75^{4}$.

The application was first dismissed in Weekly Court ${ }^{5}$ but on leave to appeal being granted, ${ }^{6}$ it began its movement upward ${ }^{7}$, terminating in the Supreme Court of Canada. There, it was ordered that the constituent plaintiffs be struck from the style of cause, reducing a $\$ 5,000,000.00$

* With the Editorial Board of the Alberta Law Review.

1. Unreported, February 8,1983 (S.C.C.).

2. This group was composed of over 800 Ontario consumers who had purchased the 1971 and 1972 Firenzas.

3. This is the equivalent of Alberta Rule 129.

4. The Ontario Rule reads as follows:

75. Where there are numerous persons having the same interest, one or more may sue or be sued or may be authorized by the court to defend on behalf of, or for the benefit of, all.

The equivalent Alberta Rule, Rule 42, is only slightly different:

When numerous persons have a common interest in the subject of an intended action, one or more of those persons may sue or be sued or may be authorized by the Court to defend on behalf of or for the benefit of all.

The Supreme Court referred to the difference as being "subtle" and dealt with these two rules as well as with their English predecessor (Order XVI, rule 9) as though they all had an identical meaning.

5. (1975) 11 O.R. (2d) 389, 66 D.L.R. (3d) 205.

6. (1976) 1 C.P.C. 51 (Ont. S.C.); Hughes J. granted leave, expressing the opinion that a representative action for damages could not be brought in the absence of a common fund.

7. (1977) 17 O.R. (2d) 193, 79 D.L.R. (3d) 718 (Ont. 4.Ct.); affd. (1979) 92 D.L.R. (3d) 100 (Ont. C.A.). 
representative action to a joined action of the four named plaintiffs. Thus, after ten years of litigation, the Naken case has yet to be determined on its merits. If the action is not discontinued and the plaintiffs are successful, it is doubtful that the damages awarded will be sufficient to satisfy costs. Moreover, the Supreme Court's decision has left over four thousand constituent plaintiffs with no cause of action, now being statute barred.

Apart, however, from the personal tragedies unique to this case, the decision of the Supreme Court is unsatisfactory from a legal point of view. To begin with, the Naken decision fails to adequately define the parameters of representative actions under our existing rules of court. This is largely the result of attempting an interpretation of the rule respecting representative actions in a partial vacuum: ${ }^{8}$

The virtue and benefit of the institution of the class action is not here on trial; only the availability of that kind of proceeding in the circumstances of this case. Neither is this issue to be resolved on the basis of weighing the advantages of the representative action for the plaintiff and the disadvantages of such an action for the defendant (although a study of these factors may assist in the process) but rather on the basis of the correct interpretation of this rule of court and its application to the circumstances of the parties to this action.

With respect, it is exactly this balance of advantages and disadvantages which surrounds the origin and history of the rule. An understanding of the difficulties created by representative actions is, therefore, prerequisite to an understanding of the rule and its limitations.

In interpreting Rule 75, the Supreme Court refers to a number of recent decisions, all of which point to one or more possible difficulties created by representative actions. These may be conveniently categorized as follows:

(1) Constituent plaintiffs (or constituent defendants) not privy to the action are bound by the decision of the court as a matter of res judicata.

(2) A constituent defendant is precluded from raising defences which are not defences held in common with the named defendant. In the case of constituent plaintiffs, a defendant is only afforded the opportunity to discover and examine the named plaintiffs and is therefore impeded in raising defences applicable only to the constituent plaintiffs.

(3) A defendant is precluded from discovering constituent plaintiffs with respect to damages not suffered by the named plaintiffs but claimed by the class.

Without undertaking a study of representative actions predating the origins of Rule 75, the Supreme Court held that the rule did not contemplate nor adequately deal with these sorts of problems. In so holding, they followed all the contemporary decisions since Markt and Co. v. Knight Steamship Co. ${ }^{9}$. These decisions took a very narrow view of the rule and sought to avoid the difficulties inherent in representative actions by limiting their scope to fact situations in which the difficulties would not arise. Naken was outside this scope and the Supreme Court was not prepared to expand the applicability of representative actions without the development of procedural rules sufficient to alleviate the difficulties. ${ }^{10}$

Had the Supreme Court looked beyond Markt and indeed, beyond the origins of the rule itself, they would have discovered that Order XVI, rule

8. Supran. 1 at $1-2$.

9. [1910] 2 K.B. 1021 (C.A.).

10. Supra n. 1 at 36. 
9 (the English predecessor to our rule ${ }^{11}$ ) developed with all the referred to difficulties in mind. Moreover, the courts of equity had developed a body of procedural rules intended to circumvent these difficulties; the application of which was to continue subsequent to the introduction of Order XVI, rule 9. Ironically, these rules are similar in nature to those called for by the Supreme Court in their plea for legislation.

As early as 1676, representative actions in the courts of equity were commonplace. These were brought by way of a Bill of Peace and were intended to settle rights as between individuals. Most often, the action would be one brought against representative defendants, as in the case of a bill brought by a parson for tithes with some parishioners being named to represent all. Occasionally, the action would be one of representative plaintiffs, as in the case of parishioners attempting to establish a modus. ${ }^{12}$ In either case, it was recognized that the constituent defendants (or plaintiffs) may be prejudiced by a decree settling an action in which they were not heard. It was also recognized, however, that unless the unnamed parties were bound by the decree, the utility and convenience of representative actions would be destroyed. In Brown $\mathrm{v}$. Vermuden, for example, the decree ordered all miners in the parish to pay the Vicar a tax on production. When a constituent miner protested that he was not bound as he had not been privy to the action, the Lord Chancellor said: ${ }^{13}$

If the Defendant should not be bound, Suits of this Nature, as in case of Inclosures, Suit against the Inhabitants for Suit to a Mill, and the like, would be infinite, and impossible to be ended.

Similarly, where a few tenants, representing all tenants of the manor, brought an action against the lord to settle customs as to fines upon deaths and alienation, a tenant not party to the action was held bound "else, where there are such Numbers, no Right could be done, if all must be Parties; for there would be perpetual Abatements". ${ }^{14}$ Thus, so long as there was a common right, the benefit of avoiding multiplicity of actions was thought to outweigh any possible prejudice an unnamed party might suffer. The rule allowing representative actions was a rule of convenience.

Pursuant to the first Judicature Act, 1873, rules of court were developed to facilitate the uniform administration of law and equity. Among these rules was Order XVI, rule 9, which read as follows:

Where there are numerous persons having the same interest in one cause or matter, one or more of such persons may sue or be sued, or may be authorized by the Court or a judge to defend in such cause or matter, on behalf or for the benefit of all persons so interested.

Courts faced with the task of interpreting this rule treated it as a codification of the pre-existing equity practice, the words "one cause or matter" being synonymous with "a common right". In Duke of Bedford v. Ellis, where several plaintiffs, on behalf of themselves and on behalf of all growers of fruit, flowers, vegetables, roots and herbs, within the meaning of the Covent Garden Market Act, 1828, sued the Duke for refusing to

11. See n. 4, supra.

12. A modus was a system for the payment of tithes otherwise than by one tenth of the annual produce. Most often, it was less onerous than payment in kind and occasionally an attempt to establish a modus resulted in a declaration that no tithes were payable.

13. (1676) 1 Chan. Cas. 272 at 277, 22 E.R. 796 at 797.

14. Brown v. Howard (1701) 1 Eq. Ca. Abr. 164 at 164, 21 E.R. 960. 
grant them preferential rights to market stands as required in the Act. Lord Macnaughton said: ${ }^{15}$

It is, of course, not necessary nowadays to go to a Court of Law in order to establish legal rights.

But in all other aspects I think the rule as to representative suits remains very much as it was a hundred years ago. From the time it was first established it has been recognized as a simple rule resting merely upon convenience.

His Lordship then went on to consider various authorities predating Order XVI, rule 9 .

In the same decision, Lord Shand pointed out that: ${ }^{16}$

The rule has been framed and adopted for a useful and important object - the saving of the multiplication of actions, with the attendant costs, in cases where one action would serve to determine the rights of a number of persons in a question with another party called as defendant. A series of different actions one after another by different plaintiffs is to be no longer necessary in cases where numerous persons have "the same interest in one cause or matter", for in such cases "one or more of such persons may sue on behalf or for the benefit of all persons so interested." The rule is obviously one of advantage not only to plaintiffs but to defendants also, in the way of saving multiplication of suits, and it is of much importance to note, as observed by my noble and learned friend Lord Macnaughten, that it only applies the practice of the Court of Chancery, of which he gives many instances, to all divisions of the High Court.

Lord Brampton, although he elsewhere in his judgment erroneously confused the application of the rule as to joinder with that as to representative actions, rightly said: ${ }^{17}$

I cannot bring my mind to doubt that if the plaintiffs are entitled to prosecute this claim in its entirety, the defence will be fraught with a great [sic] deal of undesirable embarrassment. On the other hand I think that to set it aside altogether would be to defeat the well-established procedure of the Court of Chancery, under which plaintiffs suing to uphold a legal right by a suit in equity might sue on behalf not only of themselves, but also of all others having a community of interests in the upholding of that right, and would defeat also the objects contemplated by the rules referred to made since the Judicature Act with a view to harmonise the proceedings and allow of representative actions in both divisions of the High Court of Justice.

Accordingly, Order XVI, rule 9 was, as it had always been, a rule of convenience, avoiding multiplicity of actions at the cost of some prejudice to unnamed parties.

In a sense, this early interpretation of the rule goes further than United States Federal Court Rule 23, referred to by our Supreme Court in Naken. Rule 23 requires the court to find that:

... the questions of law or fact common to the members of the class predominate over any questions affecting only individual members, and that a class action is superior to other available methods for the fair and efficient adjudication of the controversy,

whereas the balance in favour of the common right is presumed under the early interpretation of Order XVI, rule 9. Because of the interpretation the Supreme Court would give to rule 9, however, the American rule must be considered more flexible.

Order XVI, rule 9, continued to be liberally interpreted until 1910 , where, in the decision of Markt and Co. v. Knight Steamship Co. ${ }^{18}$, the pendulum swung to the opposite end of its arc. In Markt, an action was brought by a shipper of goods on behalf of itself and "on behalf of all persons with goods lately laden on board the Knight Commander".

\author{
15. [1901] A.C. 1 at 10 (H.L.). \\ 16. Id at 14. \\ 17. Id. at 22 . \\ 18. Supra n. 9.
}


The Ship was allegedly carrying contraband into Japan during the Russo-Japanese War when she was stopped and sunk by a Russian cruiser. On the question of res judicata as a factor in the interpretation of rule 9, Fletcher Moulton L.J. said: ${ }^{19}$

But that which to my mind most strikingly indicates the fundamental error of the suggestion that the circumstances of these cases justify a representative action is that I can conceive no excuse for allowing any one shipper to conduct litigation on behalf of another without his leave, and yet so as to bind him. The proper domain of a representative action is where there are like rights against a common fund, or where a class of people have a community of interest in some subject-matter. Here there is nothing of the kind.

So it was that the Court of Appeal narrowed the meaning of "one cause or matter" to situations which would avoid the problem of res judicatawhere there is a community of interest in property or a common fund. Under such conditions, a constituent plaintiff could stand in no better position than the representing plaintiff and therefore, he could not be prejudiced by any order that might be granted the representative.

Since Markt, the courts have consistently followed its narrow interpretation of the rule. Indeed, in Naken, Mr. Justice Estey, speaking for the entire court, pointed out that: ${ }^{20}$

... there may in some instances be persons who became owners of one of these automobiles under circumstances covered by the revised pleadings authorized by the Court of Appeal, who may allege personal injuries suffered by reason of and related to one or more of the alleged deficien. cies of the automobile. If the effect of the ultimate judgment in this class action is res judicata on all rights of all members of the class with respect to the acquisition of a Firenza automobile, the result would be serious in such a circumstance. The operation of the defence of res judicata has a long history in our courts, and no authority was drawn to the attention of the Court wherein a court ignored such a plea in the case of a class action.

Unfortunately, in their faithful adherence to Markt, the courts have ignored a more sensible approach to the problem of res judicata. Watson $\mathrm{v}$. Cave (No. 1) is authority for the proposition that a constituent plaintiff who may be prejudiced by his inclusion in the class, may apply to be named as a defendant in the action. In Watson, Mr. Lovering, the holder of certain Peruvian bonds, discovered that a representative action had been brought on behalf of all holders of his class of bond. An order having been issued for the appointment of a receiver, Mr. Lovering sought an appeal claiming to have been prejudiced by the order. Lord Justice James said:21

It is always possible that a person professing to represent the parties is not really representing them; but then the mode of remedying that is not for any person who thinks himself aggrieved to appeal from an order which has been professedly made on his behalf, but to make some application to the Court below, where, if a proper case is made out, no doubt the Court would allow such person to be added as a Defendant, and then he could apply as a Defendant to get rid of the order, or to take the conduct of the suit out of the hands of the Plaintiff, who professes to represent, but does not in truth represent, the wishes of the great body of the bondholders.

$\cdots$

If there be any wrong done, I have no doubt the Court below will rectify that wrong by giving the parties leave in some way or other, as Respondents, to make such application as they may be advised.

In some ways this "Watson procedure" is superior to that found within the provisions of U.S. Federal Court Rule 23. The U.S. rule, held out by Mr. Justice Estey as an example of what ought to be included in Ontario

19. Id at 1040.

20. Supra n. 1 at 31.

21. (1881) 17 Ch. 19 at 21 (C.A.). 
procedure, provides the constituent party with an opportunity to opt out of the action, thus avoiding the difficulty of res judicata. The Watson procedure also avoids the problem of res judicata but does so in a more flexible manner, one which allows the unsatisfied constituent an opportunity to oppose the action or replace the representative plaintiff. If the constituent chooses not to do so, he is still protected from the effects of res judicata, as an order in favor of the plaintiffs cannot bar a subsequent action by the constituent against his former co-defendant. Moreover, the Watson procedure provides the constituent (once he is named a defendant) with notice of subsequent steps and an opportunity to be heard. If he elects to be named a defendant simply to protect his interest in a future action, it is doubtful that he would be made liable for costs.

The major deficiency in the procedure is that it lacks a mechanism which would initially draw the constituent's attention to the representative action. U.S. Rule 23 provides for initial notice:

... the court shall direct to the members of the class the best notice practicable under the circumstances, including individual notice to all members who can be identified through reasonable effort. The notice shall advise each member that (A) the court will exclude him from the class if he so requests by a specified date; (B) the judgment, whether favorable or not, will include all members who do not request exclusion; and (C) any member who does not request exclusion may, if he desires, enter an appearance through his counsel.

In today's world of constant media bombardment, however, it is questionable whether the judicially directed notice (likely to be a newspaper ad) would be any more effective than the media coverage likely to be afforded an important representative action.

The second restriction on representative actions imposed by Markt and subsequent decisions, is a restriction arising out of the problem of unique defences. In Markt, Vaughan Williams L.J. noted that the representative action was based upon separate contracts: ${ }^{22}$

... the contracts were constituted by the bills of lading, which manifestly might differ much in their form, and as to the exceptions and probably would vary somewhat according to the nature of the goods shipped.

He then went on to note that: ${ }^{23}$

Moreover, it may be that there were contraband goods on board which justified the Russian action - it may be that some of the shippers knowingly shipped goods which were contraband of war. It may be that some of the shippers were innocent of such shipping of contraband goods. All sorts of facts and all sorts of exceptions may defeat the right of individual shippers. The case of each shipper must to my mind depend upon its own merits.

In pointing to the possibility of exceptions unique to certain contracts and the possibility of some plaintiffs having shipped contraband, Vaughan Williams L.J. goes beyond the problem of res judicata. He is concerned here with the inability of the defendant to raise defences unless they are available as against the named plaintiffs. A constituent plaintiff is not liable to pretrial examinations or cross-examination at trial but may, at the same time, be entitled to the fruits of an action brought in the name of a "fault-free" plaintiff. In order to avoid such a contingency, the words "one cause or matter" were held not to include the case of multiple contracts, at least where such contracts differ. Again, the meaning of Order XVI, rule 9, was restricted and the scope of representative actions curtailed.

22. Supra n. 9 at 1029.

23. Id. at 1030 . 
Lord Buckley, in his dissenting opinion, would have allowed the representative action with an amendment removing those plaintiffs who had had contraband laden on board the Knight Commander: ${ }^{24}$

The purpose of Order XVI, r. 9, was, I think, to extend to common law actions the flexibility which had for many years been enjoyed in actions in the Court of Chancery. If I may say so respectfully, I wholly agree with Lord Lindley that the principle upon which the rule is based forbids its restriction to cases for which an exact precedent can be found in the reports. This seems to me to be exactly a case in which the spirit, nay, more, the words, of Order XVI., r. 9, justify, and good sense requires, that the principle should be extended to a case for which I daresay no precedent is exactly to be found.

His solution to the problem of unique defences was to redefine the class so as to exclude plaintiffs to whom a fatal defence would apply.

Again, all the decisions since Markt have consistently followed the principles there laid down. Where a number of defences may be available, as in the case of multiple contracts, the possibility of a representative action is destroyed. This is not to say, however, that all cases of multiple contracts are removed from the scope of representative actions. In Cobbold et. al. v. Time Canada ttd. $^{25}$, it was clearly established that where all of the contracts are substantially identical (therefore, any defences being applicable as against every plaintiff), the case will be amenable to a representative action. Interestingly, the court in Cobbold was also faced with the additional problem that some of the constituent plaintiffs had accepted a settlement prior to the action being brought. The solution selected by Mr. Justice Stark was that articulated by Lord Buckley in Markt; an amendment was allowed to exclude from the class individuals who had selected settlement.

So too, Arnup J.A., of the Ontario Court of Appeal, selected Lord Buckley's solution to the difficulties faced by Naken et. al. In Naken, the plaintiffs founded their action upon multiple contracts of the Carlill v. Carbolic Smoke Ball ${ }^{26}$ type. The plaintiffs' argument was that in consideration for their purchase, General Motors warranted that the Firenza was durable, tough and reliable. The offer was made by way of advertisement and the style of cause failed to exclude individuals who had not seen the advertisements. Arnup J.A., was of the opinion that if this deficiency was corrected, the circumstances would otherwise be suitable to a representative action.

Mr. Justice Estey at the Supreme Court of Canada, however, in overruling the Ontario Court of Appeal, quoted with approval the words of MacKinnon A.C.J.O. in Seafarers International Union of Canada et. al. v. Lawrence ${ }^{27}$ :

As appears from Rule 75 and the authorities under it, for a representative action to be properly formed, there must be a "common interest" of the named plaintiff and those he claims to represent. If he wins, all win, because all have been injured as members of the class, and there is no separate defence available against some members of the class and not others.

Later in his judgment, Estey J. said: ${ }^{28}$

... it is not enough that the group share a "similar interest" in the sense that they have varying

24. Id at 1048.

25. (1976) 13 O.R. (2d) 567 (Ont. H.C.).

26. [1893] 1 Q.B. 256; [1891.4] All E.R. Rep. 127 (C.A.).

27. (1979) 24 O.R. (2d) 257 at 262, quoted by Estey, supran. 1 at 15.

28. Supran. 1 at 34 . 
contractual arrangements with the appellant which give rise to different but similar claims in contract relating to the same model of automobile. No doubt the claims are similar and they might even be the same in the classification of contract claims but it does not necessarily follow that all such claims under similar but not identical contracts will have "the same interest" in a contract right or the subject of a contract arising between the appellant and the respondent in the sense of s. 75.(sic). . . Indeed it is difficult to extend the rule beyond that conventional class action where the contest concerns a discernable fund or asset, and only two things remain to be determined, firstly the right in the plaintiffs to the asset in whole or in part, and secondly, the right of the individual members of the plaintiff class to a part of the class's total entitlement.

Thus, the Supreme Court chose to follow the majority in Markt, and disallow a representative action. Again they pointed to a deficiency in Ontario's rules and held out U.S. Federal Court Rule 23 as the example of what ought to be. The U.S. rule provides that no representative action may be taken unless:

... (1) the class is so numerous that joinder of all members is impracticable, (2) there are questions of law or fact common to the class, (3) the claims or defenses of the representative parties are typical of the claims or defenses of the class, and (4) the representative parties will fairly and adequately protect the interests of the class.

With respect to the problem of unique defences, prerequisites (3) and (4) are of importance. They, in essence, ensure that the group of named plaintiffs (or named defendants) is constituted so as to properly represent all interests, claims and defences. Without such provisions, the Supreme Court was unwilling to give to rule 75 what Lord Buckley had referred to as "the flexibility which had for many years been enjoyed in actions in the Court of Chancery". ${ }^{29}$

This flexibility was, in part, made possible by equity's procedure with respect to unique defences. Rather than disallow a representative action, or even narrow the class as Lord Buckley would have done, the early courts of equity saw to it that representatives of a class adequately represented all interests within that class. Essentially, Chancery practice did what U.S. Federal Court Rule 23 now does.

The first trace of this practice may be found in the case of The Mayor of York v. Pilkington ${ }^{30}$ adjudicated in 1737. This was a case in which several plaintiffs claiming rights to a fishery, brought an action against a class of defendants to quiet title. The defendants demurred, some of them claiming as lords of manors and others as occupiers of adjacent lands. The Lord Chancellor noted that in representative actions, parties not privy to the action might be prejudiced by their inability to raise unique claims, but went on to say: ${ }^{31}$

. . because a great number of actions may be brought, the court suffers such bills, though the defendants might make distinct defences, and though there was no privity between them and the city.

He then suggested that the class was sufficiently constituted so as to test all defences: ${ }^{32}$

... and it is no objection that they have separate defences; but the question is, whether the plaintiffs have a general right to the sole fishery, which extends to all the defendants; for notwithstanding the general right is tried and established, the defendants may take advantage of their several exemptions, or distinct rights.

29. Supra n. 24.

30. 26 E.R. 180; 1 Atk. 282.

31. Id. at $181 ; 284$.

32. Id. 
From this statement evolved the practice of allowing representative actions only where all the interests of unnamed parties were sufficiently represented: ${ }^{33}$

. . . and it has been long settled, that if any person has a common right against a great many of the King's subjects, inasmuch as he cannot contend with all the King's subjects, a court of equity will permit him to file a bill against some of them; taking care to bring so many persons before the Court, that their interests shall be such as to lead to a fair and honest support of the public interest; - and when a decree has been obtained, then, with respect to the individuals whose interest is so fully and honestly established, the Court, on the footing of the former decree, will carry the benefit of it into execution, against other individuals who were not parties.

And, as held by the court in the Gellatly decision: ${ }^{34}$

the Court being satisfied that the parties were fairly represented before it, and that the matter was fairly contested, made a final decision of the right, and everybody interested, although not actually present, was bound by that decision, because he was present by representation.

Unfortunately, this well founded rule of procedure seemed to have disappeared at Markt and Co. v. Knight Steamship Co. Lord Buckley, in dealing with the question of separate defences, found it more expedient to reduce the class by the exclusion of the "contraband shippers". He did so rightly, as it would have been of no benefit to instead ensure proper representation of this group. To include them among the named plaintiffs would only have created embarrassment and would have necessitated their exclusion at judgment.

So also, in the case of Naken v. General Motors, to include Firenza purchasers who had not seen the advertisements, would have created embarrassment and produced no benefit. Insofar as any other defences are concerned, however, the proper practice would have been to ensure adequate representation. It may not, for example, have been too difficult to ensure that some of the representative parties were those who had "seen some, but not all of the appellant's advertisements" or "made enquiries of the appellant or its representatives". ${ }^{35}$ In such a case, the existence of potential defences would not be an obstacle to a fair and equitable adjudication. This, after all, is no less than is required by the model American rule.

The final difficulty facing parties to a representative action is the problem of unique or personal damages. As is the case of unique defences, this problem also rises out of the inability of the defendant to discover or cross-examine a constituent plaintiff. Unlike the problem of unique defences, guidance cannot be obtained from equity procedure as practiced prior to Order XVI, rule 9, since all cases of representative actions in equity sought only injunctive or declaratory relief. After the introduction of the rule, however, damages became an available relief and any assistance in the interpretation of the rule with respect to them could be obtained from contemporary authorities.

An examination of these cases, beginning with Markt, demonstrates a further narrowing of the representative action rule. In the words of Fletcher Moulton L.J.: ${ }^{36}$

33. Weale v. The West-Middlesex Waterworks Co. (1820) 1 Jac. and W. 358 at 366, 37 E.R. 412 at 416 .

34. Commissioners of Sewers of the City of London v. Gellatly[1876] 3 Ch. 610 at 615-16. See also Adair v. New River Co (1805) 11 Ves Jun. 429 at 445, 32 E.R. 1153 at 1159.

35. These were reasons given by the Court for not allowing a representative action, supra n. 1 . at 34.

36. Supra n. 9 at 1039. 
Those in whose behalf the action (so far as it is a representative action) is brought are not responsible for the costs, and are not subject to the ordinary liabilities of litigants in respect of discovery, etc. The language of the rule appears to me to present no difficulties of construction and to make clear the limitations of its scope. They answer in all respects to what one would expect from the considerations to which I have referred.

The learned Lord Justice then goes on to limit the domain of representative actions to situations in which there exists a common fund or community of property.

Since Markt, the two-fold problem of discoveries and costs has been continuously held out to be the raison d'être of the limitation. This is best articulated by Jessup J.A., of the Ontario Court of Appeal, where in Farnham v. Fingold, he observed that: ${ }^{37}$

Rule 75 should be applied to particular cases to produce an expeditious but just result. Thus, where the members of a class have damages that must be separately assessed, it would be unjust to permit them to be claimed in a class action because the defendant would be deprived of individual discoveries, and, in the event of success, would have recourse for costs only against the named plaintiff although his costs were increased by multiple separate claims.

If this is so, then any method of avoiding the two difficulties should allow for claims of personal damages in representative actions. To allow such claims would be to give credence to the oft-quoted passage of Lord Lindley in Taff Vale Railway Co. v. Amalgamated Society of Railway Servants: ${ }^{38}$

The principle on which the rule is based forbids its restriction to cases for which an exact precedent can be found in the reports. The principle is as applicable to new cases as to old, and ought to be applied to the exigencies of modern life as occasion requires.

In fact, this has been done in some of the more recent cases.

Alberta Pork Producer's Marketing Board v. Swift Canadian Co. ${ }^{39}$ is an example of an attempt to revive the flexibility of representative actions. The case dealt with a claim brought by all persons who marketed hogs through the Alberta Pork Marketing Board, alleging that the defendant had conspired to lessen competition. Damages were assessed by totalling the losses from each individual hog transaction through the use of a certain formula. Although no common fund or community of property could be found, Mr. Justice Dea, rightly recognizing the rationale underlying the limitations imposed by the authorities, said: ${ }^{40}$

... the primary concern of the Court with respect to a representative action for damages is to ensure that the defendant is not prejudiced; in circumstances in which damages are ascertainable without the need for individual examinations for discovery, a representative action may proceed; the proper approach is to examine each case to determine if, in the circumstances, a representative action is the appropriate action.

Dea J. held that the defendant would not be prejudiced as the Marketing Board through which all transactions were conducted was a party to the action. The defendant could discover the Board with respect to each transaction and with respect to the assessment of damages. Moreover, joining the Board as a party assured the defendant of his costs, should they be awarded in his favour. The case was held to be one suitable to a representative action.

37. [1973] 2 O.R. 132 at 136 (Ont. C.A.).

38. [1901] A.C. 426 at 443 (H.L.).

39. (1982) 129 D.L.R. (3d) 411 (Alta. Q.B.).

40. Id. at 415 . 
Before discussing the novel approach to the problem of damages taken by counsel in the Naken case, it is worthwhile to note that, at least in Alberta, a defendant in a representative action may avoid any prejudice which may befall him as a result of a representing plaintiff's insolvency. If it is feared that the plaintiff will not be in a position to cover costs, the defendant may apply for security under $\mathrm{R} .593$, which reads as follows:

593. (1) Security for costs may be ordered:

(h) where an action is brought on behalf of a class and the plaintiff is not possessed of sufficient property within the jurisdiction to answer the costs of the action and it appears that the plaintiff is put forward or instigated to sue by others;

That being said, individuals attempting representative actions in Alberta need only concern themselves with problems involving discoveries as to damages and possible defences.

In Naken, counsel for the plaintiffs attempted to avoid the problem of personal damages by claiming that each plaintiff had suffered identical injury. Rather than claim for specific mechanical or structural fault in the vehicles themselves, the plaintiffs alleged that the poor performance of Firenzas generally resulted in a loss of approximately $\$ 1,000.00$ of resale value in each car. By framing their pleadings in this manner, the plaintiffs hoped to avoid any prejudice the defendant might suffer by his inability to discover constituent plaintiffs. As each plaintiff suffered the same loss, it would only be necessary to discover the representing plaintiffs with respect to their method of calculating market values and loss in market value.

This argument was accepted by the Court of Appeal who further recognized that the application, being interlocutory in nature, was to be determined on the assumption that the plaintiff's allegations were true. ${ }^{41}$ While the Supreme Court of Canada began with this same assumption ${ }^{42}$, they either lost sight of it or misunderstood the plaintiffs' pleadings: ${ }^{43}$

The question then is this: can the action, by standardizing or placing a limit on individual damages at $\$ 1,000$, and by the Court of Appeal amendment limiting the class to owners who became such in response to and in reliance upon the appellant's ads which they saw, be conducted within Rule 75 when properly applied?

... then the court would presumably . . . be required, to issue an order directing a reference to the Master of the Supreme Court to conduct such hearings as required to determine what person, if any, qualify for inclusion in the class as described in the amended statement of claim and the extent of their claim up to the $\$ 1,000$ limit.

The Court then goes on to outline the difficulty that would be encountered in trying to assess the damage suffered by each individual in the class with respect to defects in their vehicles.

With respect, what damage is suffered by a plaintiff is a question of fact, not within the domain of appellate review, particularly where the appeal is one of an application to strike out.

While they came close to doing so, the Supreme Court did not absolutely limit representative actions to situations involving a common fund or community of interest. ${ }^{44} \mathrm{It}$ is, therefore, arguable that some expansion in this area is still possible. Indeed, the Supreme Court of Canada referred to

41. Supran. 7 at 218 and 219.

42. Supran. 1 at 2.

43. Id. at 26 and 27. Emphasis added.

44. See n. 27, supra, and text thereat. 
Alberta Pork Producers Marketing Board et. al. v. Swift Canadian Co. ${ }^{45}$ with approval. Unfortunately they treated the case as one involving a common fund: ${ }^{46}$

The [Alberta] Court did not have to determine the meaning of "common interest" because, whatever else the term might include, it clearly took into contemplation by its terminology an action which involved an attack by a group upon a single, determinable fund which might be found owing to that group by the defendant.

In the end, it is uncertain how flexible representative actions may be with respect to claims for damages.

What then, does General Motors v. Naken do to the law of representative actions in Canada? Clearly, it affirms the last 70 years of judicial thought at the expense of two centuries of proven practice. It ignores the meaning given the rule at its inception and it affirms a new meaning so limited in its scope as to make representative actions well nigh impossible. It prohibits the bringing of representative actions where:

(1) there are claims for personal injuries;

(2) the action is based upon numerous contracts, unless:

(a) the contracts are substantially identical and

(b) there were no oral representations, payments by cheque or other circumstances which might give rise to personal defences;

(3) there is a tort with the possibility of a defence as against some but not all of the plaintiffs (eg. consent, contributory negligence, setoff, etc.), and

(4) Where there is the possibility of any member of the class receiving greater benefit had he brought an action on his own behalf.

Finally, it could be said that the Naken decision leaves open the door to future erosion of the rule as new difficulties with representative actions are discovered.

Despite the existence of well founded procedural rules developed in the courts of equity, the Supreme Court of Canada held that our rule, "consisting as it does of one sentence of some thirty words, is totally inadequate for employment as the base from which to launch" 47 all but the most simple actions. In so doing, the Supreme Court recommended legislative reform. In view of the effect of the Court's pronouncement on the meaning of Rule 75 , one can only hope that legislators will pay heed to their recommendation.

45. Supra n. 38.

46. Supra $\mathrm{n} .1$ at 25.

47. Id. at 36 . 